\title{
LA JUSTICIA DE LA REVOLUCión ESPAÑOLA: REFUTACIÓN DE LOS ALEGATOS BONAPARTISTAS por Lorenzo Peña
}

publ. en Memoria de 1808: Las bases axiológico-jurídicas del constitucionalismo español coord. por Lorenzo Peña y Txetxu Ausín

México/Madrid: Plaza y Valdés, 2009

ISBN: 978-84-92751-47-1

Pp. $97-129$

Sumario

0.- ¿Qué sentido tiene justificar la insurrección popular de 1808 ?

1.- El Dos de Mayo, resistencia a la agresión

2.- Lucha por la legalidad y la legitimidad

3.- Revolución popular

4.- El sentido teleológico de la Jornada del Dos de Mayo

5.- La reaccionaria monarquía bonapartista

6.- El Estatuto de Bayona

7.- Justificación de la insurrección patriótica

\section{\$0.— ¿Qué sentido tiene justificar la insurrección popular de 1808?}

¿Tiene sentido preguntarse, a dos siglos de distancia, si unos hechos históricos estaban justificados? ¿Qué verdad puede pretender un aserto de licitud o legitimidad de unas actuaciones colectivas (y de aquellas conductas individuales que las integran) cuando han transcurrido varias generaciones desde que tuvieron lugar hasta el momento en que se emite ese aserto? ¿Vale para algo cuestionarse a estas alturas qué licitud o justificación pudieron tener la insurrección de Espartaco, el fratricidio de Montiel, la expulsión de los moriscos o cualquier otro hecho histórico?

Me hago cargo de que para el historiador tales preguntas son o absurdas o, en el mejor de los casos, metafísicas, entendiendo por tales aquellas cuestiones cuya mera formulación implica rebasar el ámbito de lo científicamente acotable, de lo conceptual y metodológicamente abordable dentro de unos parámetros de rigor conformes con las prescripciones de una disciplina académica.

Ahora bien, el metafísico no puede tener ese escrúpulo, porque precisamente él está para habérselas con problemas metafísicos, o sea: cuestiones cuyo tratamiento va más allá de lo manejable con criterios y pautas de demostración de las ciencias particulares, cuestiones que transcienden las delimitaciones disciplinares para adentrarse en terrenos donde la prueba es menos estricta, por manejarse conceptos menos fácilmente circunscribibles y por traerse a colación consideraciones de una gama más variada de horizontes, a cada uno de los cuales le corresponde su respectiva especialización académica.

En mi ensayo «Los confines del saber científico» ${ }^{1}$ estudié ya cómo la escala de cientificidad es una gradación tal que hay genuinos problemas, racionalmente investigables, pero que no se ciñen a criterios y pautas de mayor rigor disciplinar; problemas que no han de desatenderse (cual han querido todos los positivistas desde Auguste Comte), aunque es menester

\footnotetext{
1. En Calculemos: matemáticas y libertad, ed. por Javier Echeverría, Javier de Lorenzo \& Lorenzo Peña, Madrid: Trotta, 1996, pp. 343-362.
} 
asumir que quien a ellos se dedique habrá de resignarse a usar cánones menos constriñentes que los del científico particular.

Por lo tanto, si es metafísica la pretensión de ir más lejos en la pregunta, desbordando los marcos infranqueables para los estudiosos de una disciplina académica bien acotada, como en nuestro caso puede ser la historia, no pasa nada, porque justamente el autor de este ensayo es un metafísico que no se arredra por esa extralimitación.

No es sólo el historiador quien puede echarse para atrás ante una pregunta acerca de la licitud de conductas colectivas de hace dos siglos. Tampoco el jurista será proclive a abordar esa indagación y hasta seguramente tenderá a pensar que tal empresa carece igualmente de sentido. Y es que el jurista moderno ha vivido en una cultura doctrinal impregnada de positivismo; en este caso se trata de juspositivismo, la tesis de que el derecho es sólo derecho positivo (una visión que tiende además a reducir el derecho positivo a la ley, a textos escritos promulgados por el legislador, tendiendo a excluir otras fuentes como valores, principios y costumbres vinculantes). Y, aunque ese enfoque juspositivista no implica descartar preguntas de licitud de comportamientos en otras culturas y en otras épocas (para cada comportamiento habrá que relativizar el juicio de licitud al ordenamiento jurídico vigente en el entorno inmediato en el que se produce), un jurista positivista será reacio a enjuiciar hechos concretos que se desarrollaron en períodos históricos, por recientes que sean, con cuyo ordenamiento no está familiarizado; aparte de que le parecerá ociosa y especulativa tal preocupación, ya que su visión del derecho estará orientada al futuro, no al pasado.

Es un apotegma jurídico que la ley mira al provenir y no se ocupa de rectificar el pasado. Justamente por eso, los hechos determinan el parte el derecho. Existen unas reglas de prescripción en virtud de las cuales, en aras de la paz civil, las situaciones consolidadas por el transcurso del tiempo han de venir justificadas ex post facto sin que se autorice su cuestionamiento. Tal vez fue injusto que se establecieran. Una vez establecidas desde hace tiempo suficiente pasan a ser hechos que ya no es lícito impugnar.

Quien esto escribe se adhiere plenamente a tal punto de vista, medular para su concepción de la aplicación de la norma vigente y del nexo entre lo jurídico y lo fáctico. ${ }^{2}$ Sin embargo, eso no impide preguntar si el establecimiento de una situación fue lícito según la norma vigente en su momento; y, por otro lado, eso no nos dice si la normativa vigente ha de constar sólo de las reglas promulgadas por el legislador o si ha de involucrar también unos cánones cuya vigencia viene de la naturaleza misma de las cosas (principios de derecho natural, según la orientación jusnaturalista que profesa el autor de este ensayo).

Es más, el mismo principio de prescripción de situaciones consolidadas implica que sí tiene sentido preguntar por la licitud o ilicitud de su establecimiento inicial, porque sólo así se entiende que se diga que, aunque haya sido un hecho ilícito, su realización con efectos continuados y persistentes a lo largo de un lapso de determinada duración — siempre que concurran ciertas circunstancias fácticas- origina un derecho del cual se carecía inicialmente.

Si el arranque de una situación consolidada puede, por lo tanto, cuestionarse en cuanto a su licitud, igualmente lo será un hecho pasado que no haya producido una situación consolidada o cuya consolidación no se haya prolongado hasta el presente.

Tal vez, aquí, lo que va a suceder es que el jurista diga que indagar la licitud o legitimidad de hechos de hace 200 años no le interesa como jurista, porque es un tema de

2. V. Lorenzo Peña, «La obligación de aplicar las normas jurídicas vigentes», número 35 de Isegoría, 2006, pp. 221-44. 
exclusivo interés histórico, al paso que el historiador rebote la pelota aludiendo a que tal pregunta sale de su ámbito disciplinar. De ser así, queda precisamente el filósofo, a la vez filósofo del derecho y filósofo de la historia, en esa confluencia interdisciplinar propia de la filosofía, para abordar un problema cuyo rechazo sólo surge de pruritos disciplinares sin duda comprensibles y hasta válidos en sus respectivas asignaturas, pero que no han de coartar nuestra ansia de buscar respuestas racionales a preguntas a las que, salvo por esos escrúpulos, nadie rehusaría sentido y pertinencia (como lo es la de saber si en 1808 llevaban más razón los patriotas o los afrancesados).

Las consideraciones de los párrafos precedentes nos sirven para contestar a objeciones a la indagación del presente ensayo que emanan de escrúpulos de metodología disciplinar $-\mathrm{y}$ de los dos campos científicos más próximos a la temática: el historiográfico y el de la doctrina jurídica- Mas persiste otra dificultad que no he abordado aún: la de saber si todo eso tiene interés a estas alturas. Muchos pueden dudarlo, pensando que, cualesquiera que sean las razones válidas para atribuir validez intrínseca a la cuestión de la justificación o licitud de una conducta pasada, carece de pertinencia temática esa cuestión cuando la conducta no se inscribe en un pasado suficientemente próximo para ser un motivo actual de preocupación.

Sin embargo, esa dificultad, si es real, desemboca en una pendiente resbaladiza. Si de acontecimientos de hace 40 lustros ya no tiene interés preguntarse por su legitimidad o justificación, ¿tampoco de acontecimientos de hace cien años? ¿Tampoco de los de hace 50 años? Creo que sería mejor ser gradualista (en esto como en todo) y optar por un reconocimiento de grados de pertinencia. La expulsión de los moriscos, de hace 80 lustros, sigue siendo de actualidad, sigue surtiendo efectos y sigue siendo una injusticia que hay que resarcir y curar. La guerra de la independencia, a mitad de camino entre 1609 y nuestro tiempo presente, tiene, digamos, el doble de actualidad, el doble de pertinencia para nosotros. La semana trágica y el inicio de la guerra del Rif (1909) tendrá cuatro veces más pertinencia. La represión del régimen totalitario de 1939-78, ocho veces más pertinencia. ${ }^{3}$

Pero los hechos de 1808-14 han tenido una honda y duradera repercusión en la historia de España, determinando la identidad colectiva del pueblo español, perviviendo en la memoria común. Es una tarea ineludible recuperarlos para esa memoria compartida.

Llegados a este punto algunos pueden objetar que lo que quita interés o pertinencia actual a los hechos históricos protagonizados por el pueblo español en 1808 no es que hayan transcurrido seis generaciones, sino la lejanía que experimentamos respecto de su horizonte mental — de sus postulados, de sus objetivos. Así, más en concreto, muchos pueden albergar el anhelo de que los españoles hubieran aprovechado la coyuntura de Bayona para instaurar una República, diciendo «jadiós!» no sólo a la dinastía intrusa sino también a la que en Bayona perpetró la fechoría de vender a la Patria; fue un motivo de deshonra la adhesión popular al Deseado (un Deseado que no correspondió para nada a tal deseo colectivo). Según tal alegato esa adhesión nos impediría compartir los esquemas de nuestros antepasados de ese período, de suerte que no podríamos ver en su gesta colectiva una hazaña que nos haga sentirnos en comunidad con ellos.

Creo que el presente ensayo contesta a esa objeción directamente. Sin duda, hubiera sido muy preferible que se optara por la República; mas es ésa una consideración abstracta: el

3. Claro que ese cálculo es mecánico: para fijar la variable dependiente - que es el grado de pertinencia - sólo toma en consideración una variable independiente. el quantum de tiempo transcurrido; hay otras variables que tienen que ver con el influjo causal (que no disminuye de manera directamente proporcional al transcurso temporal) y acaso otras más. 
sentido de la lucha del pueblo español desde el Dos de Mayo de 1808 fue el de defensa de la legalidad (igual que volvería a serlo el 18 de julio de 1936, habiendo muchas proximidades entre ambos acaecimientos históricos). Sin enarbolar la bandera de la legalidad no era posible la unión de todo el pueblo español. Y la legalidad preexistente no era republicana.

No podemos demandar a los agentes individuales y colectivos de un período histórico más que lo que en él era posible. Y, desgraciadamente, la República en España no era prácticamente posible en 1808 ni en 1814, ni siquiera en 1820. (Quizá, puestos a eso, sería más adecuada una auto-crítica de lo que hacemos o no hacemos en nuestro tiempo, cuando las cosas son distintas, en lugar de mirar con tanto desdén la gesta de nuestros antepasados.)

Aunque así el pueblo español hubiera adoptado en 1808 una opción política equivocada, habría estado en su derecho. El sentido más inmediato del levantamiento popular era la defensa de la independencia nacional y de la legalidad pisoteada por la fuerza, aunque luego la acción así encaminada se concatenara — dado el estado de la conciencia pública- con una marcha hacia la renovación política de España.

Ya el rechazo al acto imperial de fuerza que constituían la invasión militar de España (disimulada al principio) y la imposición ilegal de un rey intruso bastaba y sobraba para caracterizar la revolución española de 1808 como un acto lícito de resistencia a la opresión, autorizado por el derecho natural según la doctrina de los grandes juristas españoles del siglo de oro, especialmente los de la escuela jesuita, descollando entre ellos Juan de Mariana, que es quien mejor teorizó el problema del derecho a la insurrección frente a la tiranía. ${ }^{4}$

\section{§1.- El Dos de Mayo, resistencia a la agresión}

La insurrección del pueblo madrileño del Dos de Mayo de 1808 es una resistencia a la agresión foránea, a la invasión de tropas extranjeras que - ya sin disfraz a la altura de mayo de 1808 - han penetrado por la fuerza en España (con la complicidad, eso sí, del poder existente) para adueñarse de ella y que se han ido posesionando de las plazas militares. Es, pues, el Dos de Mayo una jornada de lucha por la independencia, pero por una independencia que se tenía hasta la irrupción violenta del invasor (a diferencia de las independencias que pueden aspirar a conseguir pueblos que ya estaban sometidos desde tiempo atrás al yugo extranjero; en tales casos el dominador foráneo tiene al menos a su favor la ventaja axiológica de preservación del orden establecido).

Ese invasor que — por la fuerza de su superioridad militar - se estaba adueñando de España no sólo era un enemigo histórico que había destruido la grandeza política de la monarquía hispana en su siglo de oro (aunque el desenlace de la guerra de sucesión de 17011714 inaugurase un siglo de alianza con Francia, sólo interrumpida en dos breves ocasiones), sino que albergaba propósitos hostiles a la nación española — sobradamente conocidos-, que incluían un plan de desmembramiento territorial de España, cuya frontera septentrional pasaría —si llegaban a consumarse tales planes— de los Pirineos al Ebro; ${ }^{5}$ en el transcurso de la guerra

4. Sobre el derecho del pueblo a la revolución, v. mi ya citado libro Estudios Republicanos: Contribución a la filosofía política y jurídica, México/Madrid: Plaza y Valdés Editores, 2009, , cp. 2, \$14 (esp. n. 40 acerca del opúsculo de Felipe González Vicén Teoría de la revolución, de 1932), así como el cp. 9, §2, donde se señala como una insuficiencia de la Declaración Universal de los Derechos Humanos de 1948 no haber recogido el derecho popular de resistencia a la opresión.

5. La pretensión de anexionar a Francia toda la ribera izquierda del Ebro (o sea, los territorios de Vasconia, Navarra, la mayor parte de Aragón y toda Cataluña) fue perseguida por Napoleón reiteradamente, aunque momentáneamente la postergara en el arreglo de Bayona. Según testimonio de Talleyrand, el 20 de marzo de 1808, en un tratado bosquejado por Izquierdo (agente 
esos planes - al principio ocultados y aun desmentidos - fueron parcialmente ejecutados en Cataluña. El pueblo español, que no desconocía esos hechos, sabía que luchaba por la integridad de la Patria. ${ }^{6}$

Que España quedara bajo el yugo francés significaba que sus hombres, sus recursos, sus minerales, sus cosechas, sus barcos, sus animales, sus puertos, sus talleres, sus caminos, sus tesoros artísticos serían conservados o destruidos, utilizados, desplazados o eliminados en virtud exclusivamente de los intereses del dominador extranjero, según su propio provecho y para él; mientras que cualquier poder directa o indirectamente emanado de la voluntad nacional - por pésimo que sea- siempre ha de tener en cuenta el interés del propio pueblo y la opinión pública interna.

\section{§2.— Lucha por la legalidad y la legitimidad}

El Dos de Mayo es la lucha del pueblo por la legalidad, por el respeto al orden jurídico, violentado y conculcado por el usurpador. Es ése quizá el aspecto de aquella batalla que ha quedado más en la sombra.

Los leguleyos del Consejo de Castilla (deslizándose sutilmente con sus argucias hacia la colaboración y la traición a la Patria $)^{7}$ tuvieron menos perspicacia que las amplias masas madrileñas, las cuales se percataron en seguida de que eran engañosas las apariencias de legalidad: S.A.I. el gran duque de Berg se había apoderado de Madrid con la aquiescencia, ciertamente, de Carlos IV y de Fernando VII, pero en el fondo lo que había hecho era perpetrar un golpe militar, forzando a los dinastas españoles a un consentimiento contrario al sentir unánime del pueblo y sin previa consulta a los órganos investidos del control de constitucionalidad, como era el Consejo de Castilla. Cabe, pues, ver en el Dos de Mayo un antecedente de otro gran movimiento de masas madrileño, el del 19 de julio de 1936, suscitado por un acontecimiento similar.

de Godoy en París), Napoleón le hizo incluir una cláusula que fijaba la frontera entre las dos monarquías en el Ebro. (V. Manuel Moreno Alonso, Napoleón: La aventura de España, Madrid: Sílex, 2004, p. 235.) En febrero de 1810 Napoleón decidirá una anexión fáctica de la ribera izquierda del Ebro al imperio francés, despojando el reino de su hermano de gran parte de su territorio (v. Moreno Alonso, p. 282.) El rey José había jurado defender la integridad territorial de España. Igual que el rey francés Felipe $V$ en 1714, el rey francés José I en 1810 faltó a la palabra empeñada de no reinar en España sin mantener la integridad de la monarquía católica. Fernando VII fue un rey felón, pero José no lo fue menos. (Sobre esa incorporación a Francia de la margen izquierda del Ebro en 1810 y sobre el decreto del 26 de enero de 1812 de anexión de Cataluña, v. Antonio Moliner Prada (ed), La guerra de la independencia en España (1808-1814), Barcelona: Nabla, 2007, p. 364.) V. también Fernando Martínez Laínez, Como lobos hambrientos: Los guerrilleros en la Guerra de la Independencia (1808-1814) (Madrid: Algaba, 2007, p. 149), quien señala que el decreto del emperador de 8 de febrero de 1810 por el cual se disponía «la segregación de las provincias hispánicas de la orilla izquierda del Ebro, fronterizas con Francia» suponía la desmembración del reino de España: "Así, de un plumazo, José quedaba como un botarate y todos sus intentos de política conciliadora reducidos a escoria. En cuanto a los afrancesados, su desconcierto quedó a la altura de su dañina ingenuidad, en el mejor de los casos».

6. Algo parecido sucedió en Holanda: impuesto Luigi Buonaparte como rey a los neerlandeses, Napoleón arrancó a ese reino varios trozos en 1809 y anexionó por decreto todo el país al Imperio francés el 13 de julio de 1810, sin mediar consulta alguna con su hermano, cuyo reino invadió sin miramientos diplomáticos.

7. El papel del consejo lo examina Miguel Artola Gallego en su libro Los orígenes de la España contemporánea (Madrid: Instituto de estudios políticos, 1975, 2ª ed.), 128ss. V. también del mismo autor La guerra de la independencia, Madrid: Espasa, 2007 p. 53, donde se recuerda que ese Consejo proclamó rey a José, felicitándolo por su promoción, después de haber avalado todas las órdenes imperiales recibidas a través de Murat. El Consejo, cuando sean derrotados los invasores en Bailén, cambiará la chaqueta, anulando las renuncias de Bayona; v. Anejo I de este volumen. A partir de ese momento trató de sabotear el proceso de regeneración constitucional emprendido por la Junta Central y luego por la regencia. 
Es más: lo que estaba en juego no era sólo la titularidad de la corona de España por un rey de la casa de Borbón o por uno de la casa Bonaparte. No estábamos ante la mera introducción de una dinastía foránea, como la llegada de Carlos I en 1517 o la de Felipe V en 1700. En ambos casos la exaltación de un extranjero al trono de España se hacía en virtud de las leyes españolas (sin que quepa entrar ahora a discutir cuánto fundamento jurídico tenían las objeciones a sendas entronizaciones).

Por el contrario, los títulos del rey intruso, José I, serán las renuncias de Carlos IV y Fernando VII a favor de Napoleón, quien a su vez transfería una corona que no era suya a su hermano mayor, Giuseppe Buonaparte Ramolino. El 1 de Mayo de 1808 nada de eso había tenido lugar, pero estaba en el aire que algo así se estaba tramando. Y justamente, aunque las renuncias de Bayona hubieran sido libres, aunque hubieran sido libremente ratificadas por el Consejo de Castilla, ${ }^{8}$ habrían constituido un golpe de estado, porque el ordenamiento jurídico español no permitía al rey transferir la corona. Ahora bien, el sentimiento popular de defensa de la ley es mucho más profundo y arraigado de lo que se piensa. ${ }^{9}$

\section{§3.- Revolución popular}

Aunque pueda resultar paradójico, dado lo recién expuesto en el apartado anterior, el Dos de Mayo es una lucha en la que el pueblo se enfrenta a los poderosos, a todos los poderes establecidos, a todas las jerarquías. ${ }^{10}$

\footnotetext{
8. Fernando Díaz-Plaja en Dos de Mayo de 1808 (Madrid: Espasa, 1996, pp. 221-2) relata las vicisitudes de la conferencia imperial y real de Bayona: el 4 de mayo, llegadas las noticias de la insurrección madrileña y su represión, los reyes-padres, Carlos IV y María Luisa, increpan en términos durísimos a su hijo Fernando ante la presencia de los franceses, achacándole la responsabilidad de lo sucedido (no al verdadero culpable). Ese mismo día, Carlos IV —retomando la corona de la que había abdicado en Aranjuez el 18 de marzo - nombra lugarteniente del Reino de España al general Murat y, al día siguiente, firma un acta de donación de la Corona de España a Napoleón Bonaparte. Otros detalles de la conferencia los cuenta Ricardo García Cárcel en El sueño de la nación indomable, Madrid: Temas de hoy, 2007, p. 69. También es muy esclarecedor el relato que hace Artola en Los orígenes de la España contemporánea, op.cit., pp. 122-3, quien recuerda la proclama del 12 de mayo en la que Fernando, su hermano Carlos (futuro pretendiente carlista) y su tío Antonio absuelven a los españoles de sus obligaciones hacia la casa de Borbón para que se sometan dócilmente a Napoleón.
}

9. Tenemos ahí una similitud con 1936. Abundan las semejanzas entre ambos momentos históricos, según lo recordaré varias veces en este trabajo.

10. La grandeza y buena parte de la aristocracia apoyaron al rey intruso en Bayona y después de Bayona; algunas de esas familias nobiliarias siguieron haciéndolo en años sucesivos. Mencionemos entre los afrancesados (cf. Antonio Moliner Prada op.cit., p. 339): el Príncipe de Masserano, los duques de Santa Fe, Campo Alange (vid. infra), Frías (mayordomo mayor de Palacio en la corte de José I), Híjar, Medinaceli, el Infantado, conde de Fernán Núñez, marqueses de Valdecorzana (Gran Chambelán) y Almenara (ministro del interior). Ronald Fraser (La maldita guerra de España: Historia social de la guerra de la independencia, 1808-1814 [trad. S. Furió], Barcelona: Crítica, 2006), p. 113, n.) ofrece una estadística detallada: sólo 17 sacerdotes participaron en la asamblea de Bayona, aunque al clero se le habían reservado en la convocatoria 50 escaños; en cambio, de los 10 escaños asignados a la grandeza, ésta ocupó nueve. Sesentaiséis grandes de España revalidaron su título prestando el juramento de fidelidad a José I. (Al terminar la guerra, los aristócratas fueron los más perdonados por el Deseado; sólo 37 tuvieron que exiliarse.) Por el contrario los insurrectos del Dos de Mayo (y la inmensa mayoría de los que siguieron su ejemplo en toda España unas semanas después) pertenecían a los estratos pobres del pueblo trabajador; v. Ronald Fraser, op.cit., pp. 97ss.: sirvientes y mozos de hostería, cocheros, asistentes de hospital, aguadores, tenderos, artesanos -oficiales y aprendices-, jornaleros y braceros, mujeres de los barrios humildes, costureras, algunos militares subalternos. Inicialmente el clero apenas participó; entre los insurrectos del Dos de Mayo no se cuenta ni un solo fraile. Y Fraser concluye (ibid., p. 117): «los pobres de las zonas urbanas se alzaron con vehemente furia antinapoleónica un mes, o poco más, antes que el Estatuto fuera formalmente aprobado. Las autoridades existentes, que eran partidarias del régimen bonapartista, o que eran sospechosas de serlo, fueron sustituidas y en ocasiones incluso asesinadas". ¿Es tan exagerado decir que la guerra de la independencia fue una lucha de clases? 
La insurrección fue condenada y estigmatizada: por los dinastas a quienes acogía en Bayona el Emperador y por todos los miembros de la familia real; por todos los cortesanos, sin excepción; por la Junta de Gobierno ${ }^{11}$ nombrada en su ausencia por Fernando VII y que presidía S.A. Serenísima el infante D. Antonio; ${ }^{12}$ por el Consejo de Castilla; ${ }^{13}$ por las audiencias y los intendentes de provincia; ${ }^{14}$ por los prelados eclesiásticos; ${ }^{15}$ por todas las

11. Sobre su actuación, v. Artola, La guerra de la independencia, op.cit., pp. $36 s s$.

12. A ese infante ya me he referido más arriba. Era hermano de Carlos IV pero partidario de su sobrino Fernando. Tras colaborar con Murat en la represión contra los patriotas madrileños ( $\mathrm{v}$. Artola, Los orígenes de la España contemporánea, op.cit., p. 124), se largó a Bayona para disfrutar, como los demás borbones, de la hospitalidad del invasor, despidiéndose de los individuos de la Junta Suprema de Gobierno con un mensaje enigmático: «A los señores de la Junta digo cómo me he marchado a Bayona» y finalizaba: «Dios nos la depare buena. ¡Adiós señores, hasta el Valle de Josafat.» (V. Ramón Mesonero Romanos, Memorias de un Setentón, Madrid: Tebas, 1975, p. 56.) Está claro que a la real familia la opción entre el pueblo español y Napoleón la situaba inequívocamente al lado del emperador. Hoy la propaganda neo-josefina desplaza el problema, aduciendo las razones que había en 1808 para preferir a José I y no a Fernando VII. Sin embargo quienes así argumentan desconocen que justamente Fernando VII -lo mismo que su tío Antonio, su padre, su madre, sus hermanos y toda la casa de Borbónestaba y estuvo de acuerdo en que la corona de España fuera para el monarca francés o para aquel a quien éste designara - concretamente José Bonaparte-. La lucha no era entre dos pretendientes, porque Fernando, una vez acogido en Bayona por su imperial huésped, no pretendió reinar en España hasta que de nuevo Napoleón, en Valençay, en diciembre de 1813, le confíe ese trono. La lucha era entre el usurpador intruso, mera figura títere del agresor, y el pueblo español que lucha por la independencia y la legalidad.

${ }^{13}$. Según lo he dicho más arriba, tras la batalla de Bailén, el Consejo se adherirá tardíamente a la causa patriótica, pero seguirá haciendo lo posible para atajar la insurrección y la renovación política de España, oponiéndose a la convocatoria de Cortes constituyentes; v. Antonio Moliner Prada op.cit., p. 67.

14. Así, el Ayuntamiento de Zamora lanzó un bando exhortando a los habitantes a tratar "con el mayor afecto y esmero" a las tropas francesas. V. Artola, Los orígenes de la España contemporánea, op.cit., 148-9. Todas las autoridades constituidas del antiguo régimen fueron partidarias de someterse a Napoleón; sólo la insurrección popular empujaría más tarde a muchos de sus individuos a cambiar de postura. Que yo sepa no hubo ni una sola institución preestablecida que se sumara al levantamiento patrítico, ni por iniciativa propia ni siquiera a la fuerza: por doquier fue menester disolver las viejas instituciones para crear otras nuevas - aunque fuera con un personal salido en gran medida de las viejas élites. Como lo dice Artola ibid., pp. 171-2) «nada en la política de las nuevas instituciones recuerda la gestión de las antiguas». "Las Juntas Supremas constituyen la negación del Antiguo Régimen [...] [siendo] un órgano nuevo, distinto y esencialmente antagónico con las reliquias institucionales existentes después de la crisis de los pasados meses". V. también Artola, La guerra de la independencia, op.cit., pp. 72ss., donde se analiza magistralmente cómo fueron los insurrectos, en nombre «del pueblo soberano", quienes arrancaron por la fuerza un cambio político, concluyendo (ibid., p. 77): «De la antigua Administración no queda el menor rastro». La proclama de la Junta murciana de mayo de 1808 afirma que ha "recaído la soberanía en el pueblo" y la gaditana del 2 de junio dice: "Un rey erigido sin potestad no es rey, y la España está en el caso de ser suya la soberanía». No es menester esperar cuatro años para que quede proclamado así el principio de la soberanía nacional, que los insurrectos esgrimen desde el arranque de la revolución.

15. Monseñor Félix Amat de Palau, arzobispo de Palmira y portavoz de la jerarquía eclesiástica (a quien hay que reconocer el mérito de no volver la chaqueta en cuanto triunfaron los patriotas insurrectos) proclamó -expresando el sentir unánime de los prelados y de las dignidades del catolicismo español-, en su pastoral del 3 de junio (ya iniciado el levantamiento popular), que a los pueblos no les corresponde para nada inmiscuirse en quién reina o gobierna, pues «Dios es quien da y quita los reinos y los imperios y quien los transfiere de una persona a otra persona, de una familia a otra familia y de una nación a otra nación o pueblo. [...] [hay que atenerse al] precepto natural de obedecer a las potestades constituidas sobre nosotros [...] No hay cosa más horrible a las luces de nuestra santa religión que la confusión y el desorden que nace en algún pueblo cuando, arrogándose algunos particulares el derecho reservado a Dios de juzgar a las supremas potestades, [...] le hacen perder el respeto y la subordinación a sus inmediatos superiores. [...] Dios es quien ha puesto en sus manos [de Napoleón] los destinos de España[...] son disposiciones de la Providencia infinitamente sabia y poderosa»: José Manuel Cuenca Toribio, La guerra de la independencia: Un conflicto decisivo (1808-1814), Madrid: Encuentro, 2006, p. 35. Secundaron el llamamiento a someterse al invasor el Patriarca de las Indias Occidentales, monseñor Ramón José de Arce, los arzobispos y obispos de Sevilla, Córdoba 
autoridades civiles y militares (desde el Capitán general Negrete hasta todos los mandos del ejército real en toda España). ${ }^{16}$

Participaron en el motín algunos eclesiásticos, pero los cardenales, arzobispos y obispos condenaron las revueltas y llamaron a respetar a los soldados franceses. ${ }^{17}$

El carácter de revolución popular implica que fue una lucha del pueblo, y más concretamente del bajo pueblo, pero también que el sentido de la lucha fue el de realizar aspiraciones populares de mayor justicia y beneficiosas para las amplias masas.

Esa justificación del levantamiento popular del Dos de Mayo como revolución popular no viene en modo alguno desmentida por la convocatoria de lo que se empezó denominando «cortes» para acabar en simple «Junta Nacional» que se reunirá en Bayona semanas después; de los 91 individuos que, como máximo, llegaron a congregarse en sus últimas sesiones sólo 20 habían sido elegidos. ${ }^{18}$

Esa espúrea conferencia congregará a un número de grandes de España y altos dignatarios de las diversas esferas. Esa reunión en territorio extranjero, bajo la bota del Emperador y a sus órdenes, ${ }^{19}$ de un conglomerado de las clases sociales más elevadas del reinado precedente corrobora que la revolución del Dos de Mayo fue una insurrección de los de abajo contra los de arriba - los cuales, en ese momento inicial de la guerra, quieren mantener a toda costa sus buenas relaciones con el invasor para intentar sacar alguna ventaja a cambio

\footnotetext{
, Ávila, Gerona (monseñor Juan Agapito Ramírez de Arellano), el obispo auxiliar de Zaragoza, Miguel Suárez de Santander, y muchos otros (v. Antonio Moliner Prada, op.cit., p. 331 y pp. 338-9). Tomaron partido por la dinastía intrusa 20 canónigos de Sevilla, 16 de Toledo, 11 de Zaragoza (ibid, p. 338). Andándose la guerra, muchos párrocos obedecieron la orden de leer a los feligreses los artículos de la Gaceta de Madrid que las autoridades les señalaran (ibid, p. 331).
}

16. Cuatro capitanes generales fueron muertos por las multitudes insurgentes por su real o presunta colaboración con el régimen intruso; v. Ronald Fraser, op.cit., p. 139 n. y p. 181 (donde se recuerda la colaboración con el régimen intruso de muchos militares de alta graduación, como el general de división Eugenio Navarro en Aragón, el Capitán General Solano en Andalucía, el capitán general Francisco de Borja en Murcia (v. Artola, La guerra de la independencia, op.cit., p. 70).

17. V. Gérard Dufour, La guerra de la independencia, Madrid: Historia 16, 1980, p. 35: «Y el ejército no fue el único en prestar ayuda a Murat: el propio Tribunal de la Inquisición, el 6 de Mayo, expidió a todos los tribunales del Santo Oficio de España una carta en la que condenaba sin la menor reticencia el alboroto escandaloso del bajo pueblo de Madrid contra las tropas del Emperador de los Franceses y recomendaba la vigilancia más activa y esmerada de todas las autoridades y cuerpos respetables de la Nación (entre ellos, por supuesto, el propio Tribunal de la Inquisición) para evitar que se repitan iguales excesos y mantener en todos los pueblos la tranquilidad y el sosiego que exige su propio interés. El 12, era el Obispo de Guadix, fray Marcos Cabello López, quien publicaba una carta pastoral dirigida al clero y a todos los fieles de su diócesis y en la que tan detestable y pernicioso ejemplo no debía repetirse en España, y que Dios no había de permitir que el horrible caos de la confusión y del desorden vuelva a manifestarse ni en la menor aldea del reino. En Segovia, donde se conoció la noticia de los acontecimientos el 4 , los propios canónigos de la catedral se ofrecieron a participar en las rondas que el Ayuntamiento mandó hacer a la tropa toda la noche con el objeto de evitar cualquier tumulto e incluso la formación de grupos que comentaran la situación. La propia Iglesia española [...] prefería entonces ver triunfar las armas de Murat antes que las de los patriotas. Es que, como vimos, estos patriotas se componían únicamente de individuos de las clases populares. Y la Iglesia, como gran parte de las clases pudientes, antes apoyaba la dependencia de España que una intervención directa del pueblo (esa anarquía que tanto pavor despertaba)». ¿No están claras las similitudes y las continuidades entre 1808 y 1936 ?

18. V. Fernando Díaz-Plaja, La guerra de la independencia, Barcelona: Planeta, 1996, p. 39.

19. V. Gérard Dufour, op.cit., p. 43, pp. 41ss. 
de su colaboración (sea el reino de Etruria — como en el caso de Fernando VII—, ${ }^{20}$ sea una renta fantástica - Carlos IV- ${ }^{21}$ sea un montón de prebendas). ${ }^{22}$

Los cortesanos españoles que Bonaparte congregó en torno a sí en Bayona no eran - salvo excepciones - ilustrados partidarios de avances sociales o políticos. En su mayoría eran simplemente hombres de poder, adictos a la razón del más fuerte y temerosos de cuanto significara acción o iniciativa de las masas populares; su adhesión a la dinastía intrusa se basaba en dos razones: la obediencia debida al mandato de Carlos IV y Fernando VII de acatar la

20. El reino de Etruria se había creado por el Tratado de Aranjuez del 21 de marzo de 1801 entre Carlos IV y Napoleón. Despojado de sus estados el duque de Parma, Fernando de Borbón, por la invasión francesa de 1896, Napoleón, destruyendo a la vez el gran ducado de Toscana en poder de los Habsburgo, transformó su territorio en reino y sentó en su trono al hijo de Fernando de Borbón, Luis, quien murió en 1803, siendo sucedido por su hijo, con la reina madre regente, María Luisa, hermana de Fernando VII (quien será la primera en salir del Palacio Real de Madrid rumbo a Bayona en la mañana del 2 de Mayo de 1808). A cambio de la erección de ese reino, España cedió a Francia, por el mencionado Tratado de Aranjuez, la Luisiana (española desde el Tratado de París de 1763), que Napoleón deseaba como zona anexa a la colonia de Santo Domingo, donde iba a restablecer la esclavitud. Al ser derrotados los colonialistas franceses por el insurrecto pueblo haitiano en 1803, Bonaparte vendió la Luisiana a los Estados Unidos - lo cual fue el origen de la expansión imperial de la Angloamérica recién independizada. Napoleón se anexionó a Francia el reino de Etruria en 1807, prometiendo a sus soberanos un cacho del conquistado Portugal, pero incumplió su promesa como tantas otras (era un hombre de deshonor). Al llegar Fernando VII a Bayona el 21 de abril de 1808, el emperador en seguida le ofreció el canje: el reino de España pasaría a la casa Bonaparte y, a cambio, Fernando sería rey de Etruria. Fernando titubeó. Al final se quedó incluso sin Etruria, simplemente con una renta millonaria que nunca fue pagada (ni podía serlo). V. Manuel Moreno Alonso, op.cit., p. 205.

21. A cambio de obtener 30 millones de reales de renta anual (suma imposible de pagar), el monarca depuesto por el motín de Aranjuez fue incluso más lejos que su hijo en la traición a la Patria (una traición consumada por todos los adultos de la familia real), instando a Napoleón a entrar en España a sangre y fuego para reconquistar el trono y restablecer la situación contra la chusma insurrecta. (V. Manuel Moreno Alonso, op.cit., p. 210.)

22. V. Ricardo García Cárcel, op.cit., p. 107: «En definitiva, los primeros centros neurálgicos fueron Oviedo, que extendió la revuelta a Santander y La Coruña; Valencia, que la extiende a Tortosa, Tarragona, Alicante, Cartagena y Murcia; Zaragoza, que la proyecta hacia Lérida y Teruel; y Sevilla, que la difunde por Badajoz, Córdoba, Jaén, Granada, Málaga, Almería, Cádiz y Canarias». Ese historiador menciona también los levantamientos de León, Zamora, Valladolid y Salamanca. Por su parte Gérard Dufour, op.cit., p. 43, señala que, entre el 22 de mayo en que se levanta Cartagena y el 30 (insurrección de Badajoz), toda España se alza contra el invasor y sus colaboradores, mencionando las insurrecciones de Palma, Gerona y Manresa. (Las ciudades que no se sublevan estaban ocupadas en general por las tropas napoleónicas.) Y ese autor añade: «Es la escisión de España en dos bandos: patriotas y traidores o afrancesados. Traidores que el pueblo, ya sin respeto por el rango social o los cargos administrativos, no duda en ejecutar. El conde de Albalat en Valencia, el conde del Águila en Sevilla, el gobernador conde de la Torre del Fresno en Badajoz, los corregidores de Vélez Málaga y La Carolina, los generales Solano en Cádiz y Trujillo, en Granada, encabezan una larga lista de víctimas que pagaron con su vida [...] su obediencia a las órdenes de Madrid y su obsesión por el mantenimiento del orden. Terror contra terror, el pueblo respondía así a las represalias de Murat el 3 de Mayo. [...] lo que importa es el carácter revolucionario de semejante justicia popular ...». Fraser (op.cit., p. 183) recuerda que la cuarta parte de los ejecutados por la muchedumbre insurrecta eran corregidores locales, muchos de ellos militares. Fraser añade (p. 184): «La venganza social en Cataluña fue también la más alta». Nuevamente son palpables las semejanzas con lo de 1936. En total se formaron 18 Juntas Supremas provinciales (v. Antonio Moliner Prada op.cit., p. 59), que ejercieron un poder insurreccional, que acabaría desembocando en la Junta Central (constituida en el Palacio de Aranjuez el 25 de septiembre de 1808 como gobierno supremo de la Nación con el título de Majestad, antes siempre reservado al rey) y, más tarde, en las Cortes de Cádiz. La creación de las nuevas instituciones derribó el sistema piramidal del antiguo régimen; de un modo u otro las nuevas autoridades insurreccionales emanaban de la multitud y en algunos casos, como en Huelva, pronto se organizaron elecciones (v. Fraser, op.cit., p. 193 n.). Como lo recuerda García Cárcel, op.cit., p. 130, la Junta Central luchó contra la dispersión, la desorganización y la indisciplina, tratando de construir un aparato militar en la zona insurrecta mediante el alistamiento y la creación de milicias. Nueva similitud con los esfuerzos del gobierno republicano desde el otoño de 1936. 
entronización de los Bonaparte y el deseo de conservar así, con el Trono de José I, ${ }^{23}$ los privilegios de la grandeza y de las clases altas y —en la medida de lo posible — las viejas instituciones, salvo alguna pincelada cosmética. ${ }^{24}$

Cuando la sanguinaria represión del levantamiento popular madrileño acabe provocando la sublevación de toda España unas semanas después, ${ }^{25}$ las clases rectoras se dejarán entonces arrastrar (a regañadientes) a secundar el alzamiento nacional, no faltando entre ellas una minoría que siga colaborando con el régimen intruso hasta fines de 1813. Esa posterior concatenación de los acontecimientos no debe hacer olvidar el alineamiento inicial. No son actores ni instigadores de las acciones de masas de la primavera de 1808 quienes ulteriormente se avendrán a presidir una lucha que ellos, al comienzo, se habían esforzado por impedir e incluso (en la medida en que estaba en su mano) por aplastar.

23. Es significativo el comentario del afrancesado Juan Antonio Llorente, detentador de altos cargos en el gobierno intruso e implicado en serias corruptelas y malversaciones (como no podía ser menos en la casta privilegiada de un régimen de espolio y saqueo). Escribe el citado presbítero a Fernando VII en 1815 para implorar su perdón: «Yo he sido y soy realista por opinión. Creí ser útil a mi Patria y conservar la monarquía contra el sistema republicano. [...] Si los sublevados no hubieran promovido la guerra civil, [...] [el] resultado hubiera sido una de dos. O llegaba el día de ser vencido Napoleón, o no. Si nunca lo fuere, V.M. proseguiría tal vez privado del trono; pero la España estaría íntegra, sin pueblos quemados, ni familias empobrecidas y conservaría sus Américas. Si Napoleón cayese, V.M. volvería al trono, como su tío de Nápoles y otros soberanos, sin hacer infeliz la España para muchos tiempos[...] Solamente la existencia del gobierno de José impidió la declaración de república española». (José L. Gómez Urdáñez y otros (eds), Textos y documentos de historia moderna y contemporánea (Siglos XVIII-XX), Barcelona: Labor, 1985, pp. 127-30.) Está clara la argumentación de ese eclesiástico josefino (muy similar a la de otros eclesiásticos en los años 1936 y siguientes): el agresor, el golpista, viene exonerado de culpa, haciéndose recaer la responsabilidad en las masas populares por resistir a la fuerza y a la ilegalidad. Pero lo esencial no es eso, sino el antirepublicanismo con que se justifica la traición a la patria. Lamentablemente el pueblo español no estaba aún presto para la República, pero es sintomático que la iniciativa popular en los asuntos políticos siempre se vea como un amago de republicanismo.

24. Como lo cuenta Ramón Mesonero Romanos (op.cit., pp. 57-8), prodújose la exaltación al trono del rey José I en Madrid el día de Santiago Apóstol, 25 de julio de 1808, en una ceremonia pomposa organizada por el Ayuntamiento de la capital y el Consejo de Castilla, ostentando en ella el estandarte real el conde de Campo Alange. (Describe gráficamente la ceremonia Fernando Díaz-Plaja, La guerra de la independencia, op.cit., pp. 44-5.) Menos de una semana después, derrotados los franceses en Bailén, abandonó precipitadamente la Corte el rey intruso; entonces las autoridades patrióticas (Mesonero, ibid., p. 59) confiscaron los palacios de los principales traidores a la Nación: el duque de Frías, los Negretes, Mazarredo, Urquijo, Azanza, Ofarril, marqués Caballero, Cabarrús, varios consejeros de Catilla, canónigos, jueces y aristócratas. Ese mismo Consejo de Castilla, para hacer olvidar su afrancesamiento de los meses anteriores, avaló legalmente las confiscaciones.

25. No hay que olvidar que, si bien el pueblo trabajador fue el principal partícipe y agente de la insurrección nacional, estuvieron a su lado numerosos intelectuales: los poetas Manuel José Quintana y Lorenzo, Juan Bautista Arriaga, Francisco Sánchez Barbero, Antonio Sabiñón, Cristóbal Beña; los pensadores Francisco Martínez Marina y Gaspar Melchor de Jovellanos, el economista Álvaro Flórez Estrada (vocal de la Junta de Oviedo); hombres de leyes como Miguel de Lardizábal, Agustín Argüelles, José Canga Argüelles, Juan Romero Alpuente y Roberto Antillón (vocales, éstos dos, de la Junta de Teruel), Lorenzo Calvo de Rozas (representante de Aragón en la Junta Central; v. el Anejo II de este volumen); hombres cultos como los hermanos Bertrán de Lis en Valencia (quienes desde el inicio de la lucha propusieron una reforma del Estado a través de unas cortes constituyentes; v. Antonio Moliner, op.cit., p. 60); una pléyade de escritores, maestros, hombres del mundo de la librería y la edición y particularmente periodistas (la prensa patriótica gaditana marcará el verdadero inicio del periodismo español); así como, desde luego, muchos clérigos - hasta algún obispo. Pusiéronse al lado del invasor los intelectuales orgánicos, los Meléndez Valdés, Moratín y algunos cortesanos más. No faltó la España 3, representada por figuras oscilantes como Blanco White. 


\section{§4.— El sentido teleológico de la Jornada del Dos de Mayo}

¿Han de interpretarse los acontecimientos históricos en virtud de sus efectos causales y de su inserción en hechos de larga duración, según parecen aconsejarlo la hermenéutica racional y una buena metodología historiográfica?

Los hechos que se inician en la Jornada del Dos de Mayo podemos abordarlos, efectivamente, con una mirada ex post facto, desde lo que vino después, dándoles un sentido o una explicación teleológica en función de la cadena de acaecimientos posteriores que de ellos arrancará. ¿Cuáles son?

Uno de ellos, desde luego, es la capitalización de la rebelión por los estratos privilegiados de la monarquía y sus representantes. Siendo eso verdad, habría que señalar que esa insurrección va a desencadenar un revolucionario proceso de cambio político que desembocará en las Cortes de Cádiz y en la primera Constitución verdaderamente española, la de 1812, una Constitución democrática en la que se enuncian varios derechos fundamentales del individuo humano: los derechos a la libertad individual, a la justicia, a la intimidad familiar y hogareña, a la instrucción y a la libre e igualitaria representación política. ${ }^{26}$

Además de eso - y dejando de lado tal mirada retrospectiva- ya desde su arranque la lucha popular del Dos de Mayo no fue, en absoluto, un combate contra las innovaciones o las mejoras cosméticas con las que más tarde se adornará el poder de la dinastía intrusa; en mayo de 1808 no estaba anunciada ni una sola de tales reformas (que generalmente se quedarán en papel mojado y que, en cambio, serán asumidas y profundizadas por la verdadera revolución legislativa, que será la que llevarán a cabo las Cortes de Cádiz).

Es posible que hubiera entre las personas que se movilizaron en la Jornada - y entre quienes habían caldeado los ánimos entre la población los días precedentes, llenos de tensión e incidentes callejeros - individuos cuyo sentimiento antifrancés emanara de ideas reaccionarias o de la equivocada percepción de Bonaparte como heredero de la revolución. Sin embargo, las amplias masas populares que se arrojaron a una lucha a muerte - igual que las que semanas después se alzarán en armas en toda España - no estaban motivadas por esas ideas, no luchaban por el mantenimiento de la inquisición ni contra el racionalismo de Voltaire ni nada por el estilo, sino sencillamente contra una usurpación armada, contra una imposición por la fuerza de un poder extranjero, contra un violentamiento despiadado y brutal del sentimiento y de la voluntad de la abrumadora mayoría de la nación.

Si ya resulta forzado interpretar el levantamiento popular del Dos de Mayo desde la capitalización posterior del mismo por los viejos estamentos privilegiados — cuando éstos, percatándose de la imposibilidad de resistir al pueblo, se vean obligados a enfrentarse al poder intruso—, aún más obviamente erróneo es entender la lucha patriótica de 1808 —o la de toda la contienda hasta 1814 - como lucha a favor del absolutismo de Fernando VII.

Los madrileños de mayo de 1808 sólo luchaban contra algo, que era la agresión extranjera, que era una opresión que se imponía al pueblo español; quienes, en pos de ellos, continuarán la guerra revolucionaria lucharán por la España democrática de la Constitución gaditana (aunque haya entre ellos partidarios del absolutismo y del oscurantismo inquisitorial).

\footnotetext{
26. D. Álvaro Flórez Estrada, uno de los jefes de la insurrección patriótica y vocal de la Junta insurreccional asturiana, propuso la convocatoria de unas Cortes constituyentes ya en fecha muy temprana, el 11 de junio de 1808, o sea cinco semanas después del Dos de Mayo. La historiografía neo-josefina, que dibuja una imagen retardataria del levantamiento popular, olvida esos datos. V. Antonio Moliner Prada, op.cit., p. 63.
} 
Carece de fundamento contraponer a lo que de hecho resultó al concluirse aquella guerra —el poder de un déspota que abroga la Constitución democrática y persigue con saña a la mayoría de quienes habían luchado contra el invasor - una hipotética dinastía Bonaparte que habría reinado respetando su propia constitución.

El Estatuto de Bayona nunca fue aplicado ni respetado —ni podía serlo. ${ }^{27}$ No podía reinar constitucionalmente un monarca impuesto por la fuerza que reconoce tener contra él a una nación de doce millones de habitantes (o sea a todos) y no contar con más partidarios que quienes viajaban en su séquito. ${ }^{28}$

Y es que, además de que el modelo que tomaba — la monarquía imperial de Napoleónsólo era constitucional nominalmente, el poder real estuvo en manos del emperador y sus generales, al paso que el rey intruso era todavía menos que un testaferro o un jefe de Estado marioneta, porque ni siquiera Napoleón se dignaba consultarle sus grandes decisiones políticas con relación a España, a la que siempre trató como país conquistado.

Por último, la interpretación retrospectiva de lo que hizo el pueblo de Madrid en 1808 no ha de verse desde lo que pasó en 1814 (en virtud del tratado de Valençay del 11 de diciembre de 1813, en el que Napoleón decidió desdeñar a la nación española que lo había derrotado, para entenderse de nuevo con Fernando VII).

Habrá de verse desde todo el avance liberal del siglo XIX. No porque los patriotas que luchaban en las calles de Madrid en aquella jornada tuvieran una adivinación del futuro, sino porque el sentido de unos hechos históricos, si ha de darse desde sus efectos, habrá de valorarse tomando el curso de tales efectos en un módulo suficiente dilatado.

Aunque el pueblo de Madrid ya había hecho acto de presencia en el motín de 1766, sólo con la insurrección del Dos de Mayo inaugura una nueva etapa en la que las masas son protagonistas, al paso que las clases altas han dejado de detentar el monopolio de la acción política.

Sin el Dos de Mayo de 1808 no habría sido posible la revolución de 1820; sin ésta, tampoco se habría producido la evolución liberal de 1833 a 1843, ni la revolución de 1854, ni la de 1868 ni la II República de 1931, que culminó esa marcha ascendente.

27. V. el apartado 6 de este ensayo.

28. Fernando Díaz-Plaja en Dos de Mayo de 1808, op.cit., pp. 215-6, cita la carta de José I a su hermano —de fecha 1808-0724- contestando a su exhortación de conquistar su trono como lo habían hecho Enrique IV y Felipe V: «Enrique IV tuvo un partido. Felipe $\mathrm{V}$ no tuvo que luchar sino con un competidor. Yo tengo por enemigo a una nación de doce millones de almas, bravas, irritadas hasta lo indecible. [...] Cualesquiera que sean los sucesos, y a ellos me atengo, esta carta recordará siempre a V.M. que yo tenía razón. Las gentes honradas no me son más adictas que los pillos. No, señor. Estáis en un error. Vuestra gloria se estrellará en España». El 14 de agosto de 1808, José envía otra carta a Napoleón (v. Miguel Artola, Los afrancesados, Madrid: Turner, 1976, p. 133) en la que reconoce que él no se mantendrá en el trono «si no es tratando a los españoles como éstos trataron a los vasallos de Montezuma» (algo que no le gustaba, evidentemente, sin que por ello renunciase a la corona usurpada). El rey intruso había escrito ya a su hermano desde Vitoria el 12 de julio (v. Manuel Moreno Alonso, op.cit., p. 251): «ni un solo español me apoya excepto el corto número de personas que han asistido a la junta y que viajan conmigo»; y en otra misiva: «No estoy asustado por mi posición, pero es una posición histórica singular: aquí no tengo ni un solo partidario». A Napoleón no le importaba nada que los tuviera o no. Para él (seguidor de las ideas de Maquiavelo) los pueblos estaban hechos para someterse al más fuerte y los españoles no eran una excepción. Dice Moreno Alonso (ibid.): «El emperador [...] siempre creyó que los españoles eran como todos los pueblos y por ello no formaban una clase aparte». Se equivocó, y sus generales se lo advertirían repetidas veces a lo largo de la guerra. La despiadada represión, que había aplastado los conatos de resistencia en Egipto y el Sur de Italia, no logró extinguir a tiempo la llamarada española (una nueva similitud con lo de 1936-39, si comparamos los casos de España, por un lado, y Albania y Checoslovaquia, por otro). 


\section{§5.- La reaccionaria monarquía bonapartista}

La Francia contra la que los españoles se alzaron en armas no era la Francia de la revolución. Bonaparte, al perpetrar su golpe de estado militar del 9 de noviembre de 1799 (18 de Brumario del año VIII) declaró: «La revolución se acabó».

Entre 1799 y 1808 el general Bonaparte arrasó y destruyó toda la obra revolucionaria, de la cual sólo conservó la bandera tricolor, un par de palabras en la jerga legislativa y unas pocas reformas en el ámbito del derecho privado. Aun en ese terreno llevó a cabo una honda contrarrevolución, que se plasmó en el reaccionario Código Civil de 1804, el cual abandonaba casi todos los avances de la revolución en el ámbito del derecho de familia y sometía a la mujer a un régimen matrimonial en algunos aspectos más inicuo que el anterior a $1789 .{ }^{29}$

El emperador Napoleón había anulado la libertad individual; censurado y amordazado a la prensa; restaurado el catolicismo como religión oficial del Estado por el Concordato de $1802 ;^{30}$ domesticado y reducido a mera apariencia las instituciones electivas (con sufragio censitario); ${ }^{31}$ eliminado la división de poderes; restablecido la esclavitud en 1803; restaurado la monarquía (consagrado emperador por el Papa Pío VII, se coronó a sí mismo como soberano

29. Anne Lefebvre-Teillard, Introduction historique au droit des personnes et de la famille, París: PUF, 1996, p. 207. En el viejo derecho francés, la subordinación económica y jurídica de la mujer en el matrimonio venía atenuada por varias instituciones legales: ganancias de supervivencia, derechos sucesorios en algunos ordenamientos consuetudinarios que tenían el aval regio. Todo eso lo suprimió el Código napoleónico de 1804. Ese mismo Código (v. ibid., p. 351) autoriza también al padre a encarcelar a sus hijos menores de edad: hasta los 16 años el presidente del tribunal de distrito no puede rehusar la orden paterna; la intención de Bonaparte era la de extender ese poder paterno más allá de los 18 años sin control judicial, pero el Tribunado, en sus últimos coletazos de indocilidad, consiguió frenar tales extremos de despotismo doméstico.

30. François G. Dreyfus (en Le temps des révolutions: 1787-1870, París: Larousse, 1968, p. 136) señala que desde el período del consulado (la ley del 11 de floreal del año X) la mayoría de las escuelas cayeron, gracias al Concordato con la Santa Sede, en manos de los hermanos de la Doctrina cristiana y de las monjas. El mismo autor muestra (ibid., p. 137) el carácter totalitario y despótico de la Universidad Imperial creada en 1806; según un decreto de 1808 todas las enseñanzas en Francia debían basarse en estas reglas: «los preceptos de la religión católica, la fidelidad al Emperador y a la dinastía napoleónica». Además esa Iglesia católica-romana, de nuevo convertida en religión oficial del Estado, cae también bajo la férula de Bonaparte, que es quien, según el concordato, tiene potestad para nombrar a los arzobispos y obispos. El tirano no consentía ni el más mínimo resquicio de disidencia o de discrepancia con su omnímoda voluntad.

31. Georges Burdeau, F. Hamon y Michel Troper, en su Droit constitutionnel (París: LGDJ, 1995, 14a ed., pp. 308ss), muestran el itinerario de la implantación de la dictadura napoleónica: si en la constitución consular del año VIII (la promulgada por Bonaparte nada más perpetrar su golpe de Estado del 18 de Brumario, que destruyó las instituciones de la República) se restablece el sufragio universal masculino, es porque los electores no eligen a nadie, sino sólo proponen; implántase un sistema piramidal en el cual, desde el escalón más bajo, los «representantes» vienen nombrados por arriba; en la cúspide es el Primer Cónsul el que hace los nombramientos principales. Inicialmente el Senado reclutaba por cooptación y designaba a los miembros del Cuerpo legislativo, del tribunado y del tribunal de casación, mientras que el jefe del Estado ya se reservaba el monopolio de promulgar las leyes (detentando en exclusiva la iniciativa legislativa) y nombrar a los ministros y altos cargos. El Tribunado delibera y no vota; el cuerpo legislativo vota y no delibera. El primero será duramente sancionado por discutir algunas iniciativas del Primer Cónsul; tras otras peripecias, en 1807 Napoleón lo suprime. Las sucesivas enmiendas de la "constitución» van concentrando cada vez más todo el poder legislativo, ejecutivo y judicial en las manos del Emperador, quien designará solo a los integrantes de las cámaras y de los cuerpos institucionales. Desde 1807 las leyes que emanen del emperador no serán discutidas por nadie. En la práctica Napoleón prescinde incluso de la formalidad de una votación (sin debate) en el cuerpo legislativo, que él nombra. Como lo dice Jean-Jacques Israel en su libro Droit des libertés fondamentales (París: LGDJ, 1998, pp. 118-9), el Senado, al que siguieron incumbiendo en teoría algunas facultades de control, jamás las ejerció: no se opuso nunca a la promulgación de ninguna ley por el emperador; la comisión senatorial de libertad de prensa sólo ocho veces consideró reclamaciones, que no prosperaron ni en un solo caso. La dictadura no tenía freno alguno. 
1804) ${ }^{32}$ reintroducido la aristocracia, incluso con mayorazgos y con patrimonios nobiliarios inalienables o de manos muertas; ${ }^{33}$ estaban perseguidos los intelectuales racionalistas (los idéologues, p.ej.), ${ }^{34}$ los escritores de tendencia liberal y los pensadores independientes; ${ }^{35} \mathrm{el}$ pueblo francés vivía bajo una dictadura militar y policíaca, ${ }^{36}$ mucho más opresiva y asfixiante que el antiguo régimen. ${ }^{37}$

32. Jean-Pierre Royer, Histoire de la justice en Fance, París: PUF, 1995) recuerda las etapas: un senado-consulto del 4 de agosto de 1802 implanta el consulado vitalicio del dictador, al que el senado-consulto del 8 de mayo de 1804 convierte en monarca hereditario e iniciador de una nueva dinastía. Ese autor analiza también jurídicamente cómo se pasa a una monarquía absoluta, sin ninguna atenuación constitucional: el 16 de septiembre de 1807 (ibid., p. 438), la tarea de interpretar la ley viene conferida al emperador, mediante un reglamento de administración pública. La Corte de Casación, tribunal supremo, es nombrada por el monarca (v. también ibid., p. 453).

33. V. Anne Lefebvre-Teillard, op.cit, p. 357.

34. Émile Bréhier, en su Histoire de la philosophie, t. II (La philosophie moderne), fasc. 3 (París: PUF, 1968, $5^{\text {a }}$ ed. corr. por L. Jerphagnon y P.-M. Schuhl), dice (pp. 529-30): al perpetrar el general Bonaparte su golpe de Estado del 9 de noviembre de 1799, el grupo de los ideólogos — seguidores de las ideas de Condillac - eran partidarios suyos: Volney, Garat, Sieyès, Cabanis, Destutt de Tracy y otros. En seguida caen en desgracia por sus expresiones de libre opinión, manifestadas en las tertulias de los salones de la señoras Helvétius, Condorcet y Lebreton, donde se guardaba el espíritu del siglo de las luces. El dictador militar reacciona con vigor a tal disidencia. En 1803 suprime la Academia de ciencias morales. Los decretos que fundan la Universidad imperial vienen elaborados por los elementos tradicionalistas y retrógrados, hostiles a la ideología: Fontanes, amigo de Chateaubriand, el cardenal Bausset, de Bonald. Desde 1804 se endurece la persecución antiilustrada; en 1812 Napoleón acusa a los ideólogos de fomentar el espíritu de desobediencia: "C'est à l'idéologie, cette ténébreuse métaphysique qui, en recherchant avec subtilité les causes premières, veut sur ces bases fonder la législation des peuples, au lieu d'approprier les lois à la connaissance du coeur humain et aux leçons de l'histoire, qu'il faut attribuer tous les malheurs qui éprouvent notre belle France». Es principalmente contra Destutt de Tracy —el intelectual admirado de Jefferson - contra quien se vuelca la persecución, porque ese pensador aborrecía una educación sólo tendente a asegurar el poder político de un soberano mediante la religión, limitando la enseñanza a las ciencias exactas y a la erudición, para rehuir la funesta manía de pensar, condenando en particular la filosofía. Sin embargo también la tendencia de Chateaubriand acabará siendo proscrita por la saña intolerante del Emperador.

35. Christian Ambrosi, en su libro Europa de 1789 a 1848 (trad. G. Rubio, Madrid: EDAF, 1974, p. 169) señala que el Imperio, que supo crear pintores de su epopeya, no tuvo escritores; «los que la historia ha conservado pertenecen a la oposición»: Benjamin Constant, excluido del Tribunado en 1802, Mme de Staël - exiliada en 1803-, Chateaubriand, también proscrito por el régimen desde 1804. Y es que bajo la dictadura bonapartista era perseguido todo aquel que se permitiera un pensamiento que escapara al férreo control del monarca.

36. François G. Dreyfus (op.cit., pp. 139) muestra la espantosa opresión y miseria a la que el Emperador Napoleón sometió al desgraciado pueblo francés, destruyendo las reformas fiscales de la revolución de 1789. En 1804 se restablece el impuesto indirecto sobre las mercancías del antiguo estanco, que luego se extiende a la sal y a otros productos de primera necesidad; se crean nuevos monopolios y se restauran los viejos (el estanco). El nuevo monarca actúa con una implacable beligerancia contra las clases pobres aún más que lo había hecho la dinastía derrocada en 1792 (ibid., pp. 141-2): «la politique sociale [...] consista essentiellement à lutter contre l'ouvrier, l'empêcher de se soulever, en particulier quand il manquait de travail [...] les ouvriers restaient des parias [...] Considérés comme dangereux il furent étroitement surveillés. [...] La coalition des ouvriers fut toujours sévèrement punie, celle des chefs et des meneurs plus encore. Le droit de grève était évidemment interdit. Bien plus, un article du Code Civil, qui venait d'être promulgué, l'article 1781, décidait que le maître devait être cru sur parole en matière de salaire». Así las clases menesterosas en Francia viven en esos años bajo un yugo más duro que el antiguo régimen.

37. François G. Dreyfus (op.cit., pp. 132-3) afirma a este respecto: «Mais ce furent surtout les pouvoirs de l'empereur qui se développèrent au cours de ces années [1804-1814], jusqu'à aboutir à une dictature. Celle-ci fut mise sur pied progressivement. La police accrut son importance [...] La censure réapparut et s'exerça même sur la correspondance privée. [...] En même temps on installa un véritable système de police politique. La police était alors partout et il y eut, surtout après 1807 , de nombreuses arrestations et autres mesures privatives de liberté, tel l'exil que l'on utilisa contre les écrivains. La presse fut d'ailleurs étroitement surveillée[...] le Moniteur est le journal de l'empereur. La lutte fut de plus en plus vive contre la presse; en 1811 il 
Si de la contrarrevolucionaria monarquía bonapartista al norte de los Pirineos pasamos a la que se implantó como consecuencia de la invasión napoleónica en España, hay que refutar la falsedad de que ésta fuera mejor que el poder que vendría después de 1813. Los ejércitos de Fernando VII no incendiaban las aldeas, no mataban a la población, ${ }^{38}$ no violaban a las mujeres, no arrasaban ni saqueaban pueblos y ciudades, no prendían fuego a las cosechas ni quemaban las chozas de los campesinos, ${ }^{39}$ no destruían las fábricas ni devastaban el territorio. $^{40}$

La cruel represión del poder absolutista (1814-20 y 1823-33) iba dirigida principalmente contra la minoría culta y liberal (aunque evidentemente a consecuencia de ella también hubo muchas víctimas del pueblo bajo).

n'y eut plus que quatre journaux à Paris et un seul par département, tous sous le contrôle du gouvernement ou de ses agents. La librairie et l'imprimerie ne sont pas plus libres. Une direction générale leur est imposée avec la censure des ouvrages. C'est ainsi que le gouvernement luttera contre Chateaubriand et $\mathrm{M}^{\mathrm{me}}$ de Staël. Le théâtre lui aussi est réglementé et en 1812 paraît le Décret de Moscou sur la Comédie Française. Ainsi le régime napoléonien, s'il a eu le mérite de rétablir l'ordre, a-t-il organisé une véritable dictature». Por su parte Christian Ambrosi (op.cit., p. 169) indica la opresión bajo la que vivía el pueblo francés bajo el yugo de Napoleón, cuyas incesantes guerras de conquista provocaron una espantosa calamidad pública: en 1810 los gastos militares englutían $62 \%$ del presupuesto estatal, el desempleo se extendió como una plaga, la vida económica sufrí una tremenda crisis. La respuesta popular fue la resistencia pasiva (ibid., p. 173): en 1811 había 40.000 prófugos de la conscripción imperial, al paso que el descontento era masivo. Al caer Napoleón en 1814, nadie movió un dedo ni siquiera para impedir la restauración del trono borbónico.

38. V. Fernando Martínez Laínez, op.cit., pp. 99-100: «No toda la retórica empleada por los patriotas era exagerada, ni mucho menos. La brutalidad francesa en España no tenía muchos precedentes y empujó al pueblo a pagar con la misma moneda, violencia con violencia [...] En Medina de Rioseco, julio de 1808, los franceses asesinarion fríamente a sus prisioneros españoles y, entre el saqueo generalizado de la población, aún tuvieron tiempo de degollar a todos los monjes franciscanos de la ciudad. [...] La táctica napoleónica de hacer vivir a sus ejércitos con lo que obtenían sobre el terreno suponía, en realidad, alimentar la guerra con las exacciones y los robos a la población civil. [...] Nunca se insistirá bastante en la influencia que para la formación del 'espíritu guerrillero' de buena parte de la población española tuvieron los actos de pillaje y crueldad del ejército francés. [...] El historiador italiano César Cantú lo expresa con mayor crudeza al decir que las derrotas francesas se produjeron muchas veces 'por el inmenso tren de bagajes que llevaban, producto de sus depredaciones y su alegre vida entre las licencias y la barbarie. Los generales violaban y robaban; con los diamantes quitados a las imágenes de las Vírgenes adornaban a sus mancebas; traficaban en mujeres y la conducta de los superiores parecía dar derecho a los soldados para todo linaje de astucias'. [...] Este pillaje sistemático dio como resultado un tipo de combatiente irregular desesperado y sombrío, golpeado por el sufrimiento, que ya no tenía nada que perder excepto volcar su odio matando a cuantos franceses pudiera". Martínez Laínez cuenta (ibid., p. 101) casos como el Desastre de Uclés: «las tropas francesas [...] entraron en el pueblo tal horda salvaje, robando y destrozando cuanto a su paso se presenta, [...] saquearon hasta el hospital, donde se daba asilo a los forasteros enfermos o heridos. Hicieron uso de todo género de tormentos [...] 79 vecinos fueron atados como bestias y degollados en el matadero público». Unos días después, el 13 de enero de 1809, la caballería francesa volvió a entrar en Uclés «rompiendo y robando cuanto hallaba a su paso». Ese historiador afirma que, a consecuencia de todos los hechos de la guerra de la independencia (p. 102) el número de muertos bien puede haber superado el millón de personas.

39. Artola, en La guerra de la independencia, op.cit., p. 196, recuerda la confesión del general Girardin, concretando una larga experiencia: "quemar es un placer del que no se hastiaban nuestros soldados. Prendían hasta los campos de trigo a punto de segarse; las espigas doradas por el sol ardían con facilidad suma, y no bien se había puesto fuego a un campo cuando las llamas se extendían a enorme distancia: La pasión de quemar era tan grande entre estas tropas que, apenas salíamos de las chozas en que habíamos pasado la noche, ya ardían».

40. Como lo recuerda Moreno Alonso (op.cit., p. 293): «En su avance hacia Madrid [a fines de 1808], el emperador no tuvo misericordia para con los españoles. El conde Segur, ayudante de campo del emperador, escribió en sus Memorias que, desde el Ebro a Madrid, 'se permitió al soldado gozar de su venganza y saciarse de ella'. Como un vendaval que arrasara todo a su paso, nadie osó enfrentársele». Tal crueldad y saña fue constante a lo largo de los seis años de guerra. 


\section{§6.- El Estatuto de Bayona ${ }^{41}$}

¿Introdujo el Estatuto de Bayona una monarquía constitucional en España? Si ya era un despotismo no ilustrado el modelo bajo el que Napoleón mandó redactar esa carta —otorgada luego por su hermano José_ ${ }^{42}$, el resultado de la adaptación va a ser una autocracia apenas disimulada. Todos los poderes políticos están concentrados en la persona del rey, aunque bajo la supremacía del emperador de los franceses. ${ }^{43}$

En efecto: el trono asume la plenitud del poder ejecutivo - nombrando libremente a sus ministros-; el rey es también el que designa a los senadores (art. 32), ${ }^{44}$ a los consejeros de Estado, ${ }^{45}$ a una parte de los diputados (arts. 73 y 74) y a todos los jueces (art. 99).

El senado es un préstamo francés al que apenas se atribuyen funciones: velar por la libertad de imprenta cuando ésta llegue a establecerse (art. 45) ${ }^{46}$ y la libertad individual (arts. 39 y 40) así como anular algunas decisiones de las juntas electorales; prácticamente era una cámara a la que correspondía algo así como una defensoría colectiva del pueblo. El consejo de Estado (arts. 52ss) era consultivo.

Las Cortes (arts. 61ss) eran por brazos o estamentos: clero, nobleza y pueblo o estado llano; los diputados «populares» serían: los unos nombrados por la Corona y los otros elegidos mediante sufragio censitario indirecto.

¿Eran esas Cortes estamentales y, en parte, de designación regia una cámara investida del poder legislativo? ¡No! Es verdad que el art. 82 estipulaba que se presentarían a la deliberación y aprobación de las Cortes las variaciones que tuvieran que hacerese en los códigos civil y penal así como en el sistema tributario y en el monetario. Mas presentar a tal deliberación y aprobación no implica, para nada, que sin esa aprobación carecieran de validez

\footnotetext{
41. Sobre el Estatuto de v. Antonio Moliner Prada, op.cit., p. 361. El rey «escogía los jueces, los cargos de la Administración, los miembros del Senado y parte de los diputados. [...] Frente a la ruptura que marcaron las Cortes de Cádiz, en Bayona se había acordado una reforma [...] [con] Cortes estamentales [...]».
}

42. Al parecer, el emperador no tenía al principio intención alguna de promulgar una constitución ni nada por el estilo; barajaba varias alternativas para despedazar a España, sentando en el trono de Madrid a alguno de sus hermanos; José fue el cuarto, tras dos ofrecimientos rehusados por Luciano y Luis, no habiéndose concretado el de Jerónimo. Una vez que se decidió a elaborar una carta otorgada, mandó escribirla por sus legistas franceses y luego traducirla al español, pensando promulgarla él mismo, como un donativo a la nación española. La exasperante terquedad hispánica de algunos de los junteros a quienes congregó en Bayona consiguó, al menos, que la Carta no fuera una mera copia del texto francés y que la promulgara y jurase el rey José. El texto del Estatuto de Bayona lo tomo de la colección Leyes políticas españolas fundamentales (1808-1936), ed. por E. Tierno Galván, Madrid: Tecnos, 1968.

43. Así lo estipula el art. 124: «Habrá una alianza ofensiva y defensiva perpetuamente, tanto por tierra como por mar, entre Francia y España». El Imperio Francés no quedaba obligado a tal alianza, porque su nominal constitución no se alteró. Legalmente, según la carta de Bayona, Francia podía declarar la guerra a España, la cual, en tal hipótesis, tenía que mantenerse aliada a quien le declaraba la guerra y enviar un contingente para esa guerra de agresión.

44. Eran senadores natos, según ese artículo, los infantes de España, o sea ciertos miembros de la casa Bonaparte.

45. Los arts. 52 ss en realidad no dicen quién nombra a los consejeros, pero ese silencio sólo puede interpretarse en el sentido de plena potestad regia para hacer los nombramientos, a salvo de algunos miembros natos, como los ministros, también nombrados por la Corona.

46. Para quitar hierro a esa nominal garantía, se excluía de tal protección, en el art. 45.II, a los papeles periódicos, o sea a la prensa. Incluso sobre el papel se reconocía así que nunca habría libertad de prensa periódica. 
o de vigencia. El rey presentaría sus proyectos; si las Cortes los aprobaban, bien. Y, si no, igual de bien; la aprobación de las Cortes no era ningún requisito. Dícelo a las claras el art. 86: «Los decretos del Rey que se expidan a consecuencia de deliberación y aprobación de las Cortes se promulgarán con esta fórmula: 'Oídas las Cortes'». «Oídas»: la palabra es clara.

El art. 86 no significa que haya unas disposiciones de determinado rango que sean decretos y otras que no lo sean; no se usa ahí «decreto» en el sentido de actos de ejercicio del poder reglamentario o ejecutivo (como hoy se entiende), sino justamente preceptos de la Corona, sean los que fueren. Cuando un precepto regio - es lo que nos dice el art. 86- haya sido presentado a la deliberación y (eventual) aprobación de las Cortes, cuando, por lo tanto, el precepto lo adopte el soberano «a consecuencia» de esa deliberación y aprobación (aprobación suponiendo que se dé), ${ }^{47}$ ese precepto se promulgará con la susodicha fórmula, «oídas las Cortes».

No necesitará el rey presentar a las Cortes sus proyectos de ley cuando no se trate de una variación legislativa mayor, o sea: cuando ni se trate de una modificación del código civil o del penal ni tampoco de un cambio general del sistema impositivo ni de una gran mutación monetaria. $^{48}$

Mas, tanto para las grandes variaciones de códigos o del ordenamiento tributario o monetario, ${ }^{49}$ para las que la deliberación de las Cortes (en pleno) se requiere, como para las demás leyes, para las que sólo se exige una previa comunicación a una comisión de Cortes, la potestad legislativa radica plena e incompartidamente en el Rey; en el mejor de los casos, las Cortes sólo serán oídas, nada más.

Por último a las Cortes incumbirá deliberar los proyectos de modificación de la constitución, cuya iniciativa se reserva al rey (art. 146). ${ }^{50}$

47. Nótese que la palabra «consecuencia» está tomada en sentido temporal, no causal ni, menos, de ilación lógica ni nada por el estilo. En ningún momento dice ese Estatuto que sin el voto positivo de las Cortes carezcan esos decretos de fuerza de obligar.

48. En tales casos, el art. 83 dice que le bastará al rey comunicar previamente el proyecto, a través de las secciones del consejo de Estado, a la comisión respectiva de las Cortes; no se establece que tal comisión haya de dar su aquiescencia ni, mucho menos, que tenga que presentarse al Pleno de las Cortes.

49. Notemos que, si bien el art. 113 establecía que habría un único código de comercio para España e Indias, el art. 82 no incluía las variaciones de tal código entre las que debían presentarse a deliberación de las Cortes. Así, aparentemente, la legislación mercantil sería un asunto reservado en el cual el Trono decidiría sin mediar siquiera una consulta, sin tener que ser "oídas las Cortes".

50. Ese art. en realidad lo que dice es que tales modificaciones, por orden e iniciativa regia, se presentarán a la deliberación (esta vez ni siquiera se dice "a la aprobación») de las Cortes siempre que se hagan «después del año de 1820". ¿Qué quiere decir? ¿Que antes de 1820 no podría decretar el rey ningún cambio constitucional? No puedo entrar en la mente del redactor, pero, desde luego, no es eso lo que dice la Carta; lo que dice es que, cuando los cambios constitucionales decididos por el rey se realicen después de 1820, se someterán a deliberación de las Cortes. Hasta 1820 el rey podía modificar la constitución 0 suprimirla en cualquier momento, sin consultar para nada a las Cortes. 
La Carta otorgada por José Bonaparte mantenía (con restricciones) los mayorazgos (art. 137), ${ }^{51}$ las encomiendas (art. 142), los fueros de las provincias vascongadas y Navarra (art. 144), ${ }^{52}$ la nobleza (art. 140).

¿No había ningún paso adelante en ese Estatuto con relación al régimen precedente de los Borbones? Sí, había unas pocas reformas: ${ }^{53}$ abolición del tormento (art. 133), respeto del domicilio privado (art. 126) ${ }^{54}$ derecho a la libertad individual (art. 132), supresión de aduanas interiores (art. 116), eliminación de los privilegios tributarios (art. 118) y, una vez que hayan transcurrido dos años desde la plena sumisión de los españoles a su nuevo rey, una libertad de imprenta no extensible a la prensa periódica (art. 145 en conexión con el art. 45.II). En suma unas pocas mejoras pequeñas - principalmente en el campo del derecho procesal y del tributario-, que figuraban ya en la agenda legislativa del siglo de las luces, ${ }^{55}$ aunque nuestros monarcas borbónicos jamás se habían resuelto a ponerlas en vigor.

\section{§7.- Justificación de la insurrección patriótica}

Al margen de las circunstancias históricas evocadas en los apartados precedentes, es más fundamental la razón por la que estuvo justificado el levantamiento del pueblo español contra el agresor francés. Se trata de que un pueblo tiene derecho a luchar por su independencia y soberanía cuando hay motivos de justicia básica para reclamar tal independencia, como los tenía la nación española en 1808. Motivos como son éstos dos:

(1) la existencia de la nación consolidada, consagrada por el transcurso del tiempo, claramente diferenciada de las naciones agresoras y conquistadoras y cuya legitimidad de aspiración a la existencia propia y separada pueda sostenerse ante un tribunal imparcial (a diferencia de los irredentismos secesionistas);

(2) la necesidad de esa independencia como único marco posible para la realización y salvaguardia de los derechos individuales de los hombres y mujeres que integran esa nación.

Cuando están presentes esos dos motivos de legítima lucha por la independencia nacional, pasan a segundo plano las cualidades y los defectos de los contendientes, las ventajas o desventajas de los sistemas políticos de unos o de otros, la conducta bélica de cada bando, las ideas que animan a los patriotas y a los agresores.

Aunque fuera verdad que el pueblo español hubiera estado luchando por la inquisición y contra el progreso de la revolución francesa, habría estado plenamente justificada su lucha independentista de 1808-1814, como lo está en este mismo momento la lucha antiimperialista

\footnotetext{
51. Por el art. 139 el otorgador de la Carta se reservaba el derecho de crear nuevos mayorazgos.

52. Aunque eso sólo por el momento, porque el artículo dejaba totalmente abierto qué se haría en el futuro al respecto.

53. En realidad varias de ellas ya habían sido propuestas por nuestra doctrina jurídica ilustrada, aunque los reyes siempre habían rehusado adoptarlas.

54. Ese artículo no exigía para el allanamiento de la casa de un habitante del territorio español que la orden fuera avalada por un juez, sino sólo que «dimane de la autoridad pública»; aun ese pequeño avance quedaba, así, prácticamente en nada.

55. Y que se habían implantado, p.ej., en los Estados de la casa de Austria, como la Toscana del Gran Duque Leopoldo, así como en otros reinos europeos antes incluso de la revolución francesa, que asumió esas reivindicaciones de su tiempo.
} 
de los pueblos que rehúsan ser subyugados por potencias atlánticas de la alianza boreal, por mucho que éstas transporten en sus furgones una democracia de escaparate. 